\title{
DEMOTIC CONTRACTS BETWEEN SCULPTORS AND THE BASTET TEMPLE AT THOLTHIS
}

\author{
Willy CLARYSSE* - Ulrich LUFT**
}

The texts published here are kept in the Egyptian Department of the Museum of Fine Arts at Budapest as part of a small collection of demotic papyri from cartonnage found in Gamhud in the Oxyrhynchite nome.

In a memorandum which Fülöp Back, field director of the AustroHungarian Mission presented the Imperial and Royal Embassy in Cairo he also referred to the Budapest papyri:

We also found a number of cartonnages, which are derived from mummy masks, and in which papyrus fragment can be found, with demotic, hieratic, Coptic and Greek inscriptions. All these fragments are being passed to the

Egyptian Museum to be unrolled, and to be studied, but after this they will be given to the Hungarian National Museum¹.

Back reported in a note of 1907 that Mr Blackman, who carried out excavations in Oxyrhynchos had visited Tadeusz Smolenski asking him to send the demotic papyri for investigation to Oxford. The cartonnage was given to the Hungarian National Museum and in the 1930's to the Museum of Fine Arts where papyri were gained from the cartonnage. They were finally catalogued in 1951.

The texts refer to the village of Tholthis, as do at least two other texts in this collection, which are now available in pCount 48 and pZauzich 43.

The five texts published here constitute a small archive of contracts, written to the lesonis of the temple of Bastet in the Oxyrhynchite village Tholthis in years 32 and 33 of a Ptolemaic king. From a palaeographical point of view both the third and second century are possible, and a $32^{\text {nd }}$ to $33^{\text {rd }}$ year may belong to Ptolemy II (254-252 BC), VI (150-148 BC) or VIII (139-137 BC).

\footnotetext{
* Professor of Ancient History at the Catholic University of Leuven, Fellow of the Royal Flemish Academy of Belgium.

${ }^{* *}$ Professor of Egyptology at the Eötvös Loránd University Budapest.

1. G. VöRös, Sharuna - Gamhud. The Archaeological Mission of the Austro-Hungarian Monarchy in Egypt 1907-1908, Budapest, 2008, p. 46.
} 
We prefer Ptolemy VI because in text 2 a royal wife is apparently mentioned (but see our note to text $2,1.1$ ) and because the sign for $l$ is clearly distinguished from $r$ by a diacritical sign; this is not yet common in the first half of the third century $\mathrm{BC}^{2}$. In each text a sculptor of an Oxyrhynchite temple undertakes to do some work (making a shrine or a statue or carving the hieroglyphs on a shrine?) within a certain period of time. The texts can be considered contracts of work ${ }^{3}$, though nothing similar is known to us. No specification is given of the material or the dimensions of the sculpture to be made. Perhaps the task would be given to the highest bidder, in which case text 5 is comparable to the offers for the traffic on the Birket Karun in Soknopaiou Nesos pOxf. Griffith $42-53$ (see our note to text 5, 1. 2).

The texts are ordered here according to their state of preservation. Text 1 and 2 are so similar that they may even be copies of the same contract (because the fibres do not run in the same direction, they can not be parts of a single double contract). Because of the similarity of the texts the supplements in texts 2-4 are largely based on the readings of text $1^{4}$.

For a general introduction to Egyptian sculpture and sculptors, see now J. F. Quack, in Aegypten Griechenland Rom, Abwehr und Berührung, Städelsches Kunstinstitut und städtische Galerie 26 nov. 2005 - 26 Feb. 2006, Frankfurt, 2005, pp. 50-54. A statue of a sculpture is discussed by C. RigGs, The beautiful burial in Roman Egypt, Oxford, 2005, pp. 249-252. A forthcoming article by M. Cannata, "Art without artists: a textual window on the funerary artists of Roman Egypt", deals with funerary artists (sculptors, painters, gilders, makers of mummy cases etc. $)^{5}$. In B. Porten, Textbook of Aramaic Documents from Ancient Egypt I (Letters), Jerusalem, 1986, A 6.12 (p. 120) a sculptor is to be sent to the Persian official Arsames in the late $\mathrm{V}^{\text {th }}$ century BC to make a statue of a "horse with rider". Perhaps the most famous story about a sculptor being set at work is found in the so-called dream of Nektanebo in the katochoi archive ${ }^{6}$. When the hieroglyphic texts on the walls of the sanctuary in Sebennytos have to be finished urgently, king Nektanebo engages Peteesis, the best sculptor of the country, and offers him a large amount of money ${ }^{7}$. But Peteesis spends his money and his time in the pubs (and brothels) around the temple and the work never gets done.

2. Cf. W. Clarysse, The Eponymous Priests of Ptolemaic Egypt (P. L.Bat. 24), Leiden, 1983, p. 142.

3. For contracts of work in demotic, see E. SEIDL, Ptolemäische Rechtsgeschichte ( $\ddot{A} F$ 22), Glückstadt, 1962, p. 145-151.

4. With thanks to M.-P. Chauffray, M. Chauveau, M. Depauw and S. P. Vleeming for numerous suggestions which we gratefully adopted. We are well aware that our readings are still often problematical.

5. We thank the author for giving us access to her article in advance of publication.

6. TM $65612=$ Mertens-Pack $2476=$ LDAB 6863. The basic edition is still that of Wilcken in UPZ I, 81. Koenen's reedition in BASP 22 (1985), p. 176-183 searches for a doubtful metrical pattern.

7. Contrary to Wilcken and Koenen, I do not accept the involvement of a highpriest Samaus, see "De droom van koning Nektanebo op een Griekse papyrus (UPZ 81)", in Schrijvend Verleden, documenten uit het Oude Nabije Oosten, vertaald en toegelich, 1983, pp. 367-371. 


\section{Text 1}

Inventory number: pBud. E 51.2172 A (pl. 1).

Measurements: $15.3 \times 12.2 \mathrm{~cm}$.

Light brown papyrus, somewhat dark at the right margin and at the bottom. The text is written with the fibres; the upper and right margins are preserved.

Date: 17 March 148 (Ptolemy VI) or 14 March 137 BC (Ptolemy VIII).

The text was briefly presented by U. Luft during the demotists' conference in $\mathrm{Pisa}^{8}$. A picture was published in P. NÉmeth - A. Szabó, Biblia Múzeum. Az állandó kiállítás katalógusa. Ráday Gyújtemény (Bibel-Museum. Catalogue of the works in the gallery. Collection Ráday), Budapest, 1991, p. 5, fig. 3.

\section{Transliteration}

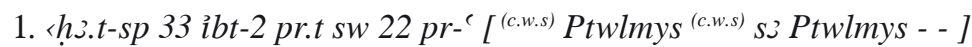

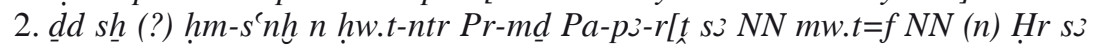
$W d j-H r]$

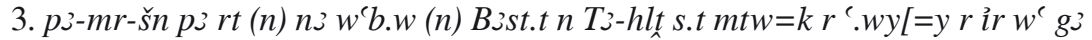
$n$ ts hw.t-ntr]

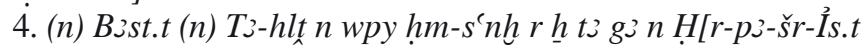

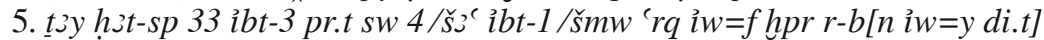

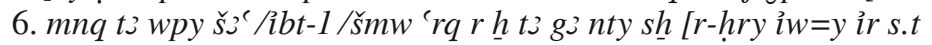

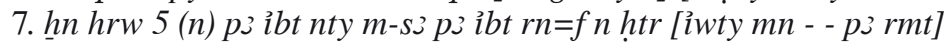

8 a.

8. $n t y$ i $w=f(r) \underline{d} d=w$ irm=y 'rn ṗ sh nty hry mtw=y ir r.h.t=f(?)' n htr ỉwty mn $r \underline{h}$ [pj] nty sh [r hry (?) [

9. [- - ] rn=s rtb sw 38 nhh 5 ..[

10. [- - ] . di.t n=i mtry...[

11. $[---]$.

\section{Translation}

1. Year 33, Mecheir 22 of pharaoh [Ptolemy son of Ptolemy and his wife]

2. has said the scribe (?) and (?) sculptor of the temple of Oxyrhynchus Papretis (?) [son of NN his mother is NN to Horos son of Oteyris]

3. the lesonis and representative of the priests of Bastet of Tholthis. I have an obligation towards you [to make a shrine (?) in (?) the temple]

4. (of) Bastet in Tholthis as work of sculptor like the shrine of $\mathrm{H}[$ arpochrates - - ]

5. from year 33 Phamenoth day 4 until Pachons 30. If [I do not ?]

6. complete the work before 30 Pachons as the shrine described above [I will do it]

7. within 5 days in the month after the specified month, necessarily [and without delay. The person]

8. who will dispute with me in the name of the writing above, I will act accordingly (?)' necessarily without delay as written [above (?)

8. U. Luft, "Demotische Papyri in Budapest", in Acta Demotica. Acts of the fifth international conference for demotists, Pisa $4^{\text {th }}-8^{\text {th }}$ September 1993 (EVO 17), 1994, pp. 191-195. 
9. - - - for (?) ] the said [work] 38 (?) artabs of wheat and 5 (hin?) of oil [

10. - - give witness (?) to me - - -

\section{Comments}

1. A date under Ptolemy II (6 April 252) is too early because in text 2 the queen is apparently mentioned alongside the king, which is impossible for Ptolemy II after the death of Arsinoe. See note on text 2, 1. 1.

2. For payments to $h m-s^{\text {'nh }}$ "sculptors" in the temple of Edfu, see M. Schentuleit, Aus der Buchhaltung des Weinmagazins im Edfu-Tempel. Der demotische P.Carlsberg 409 (The Carlsberg Papyri 9, CNI Publications 32), Copenhagen, 2006, index p. 487. The uncertain reading sh "scribe", indicates perhaps that the sculptor was responsible for the hieroglyphic texts; cf. pCarlsberg 409, fragm. 64, col. II, 1. 7, where the sculptor Psenaies "puts the writing on the stone"; idem, fragm. 114, VI, 1. 12.

2. For the name Pa-p3-rt, see Demotisches Namenbuch, p. 365; the feminine equivalent $\mathrm{Ta}-\mathrm{p}_{3}-\mathrm{rt}_{\mathrm{A}}$ appears, no doubt also in Tholthis, in pCount $48,11.5$ and 14. After the name a patronymic is expected and perhaps the name of the mother.

2-3. An anonymous archiereus (the Greek equivalent of lesonis of Tholthis is mentioned in pHib. I 62 (245 BC). The title combination "lesonis and representative of the priests" is unparalleled (information provided by MariePierre Chauffray).

3. The words $r$ ir $w^{\prime} g_{3}$ "to make a shrine" are a supplement in all three texts where we entered them. They do make sense, but it is far from certain that we filled in the right words here.

4. Though she had a temple in Tholthis, Bastet does not seem to play a role in the village onomastics; only a single Obostortais is found in pCount 48.24.

5. The timespan between Phamenoth 4 and Pachons 30 is 87 days, but day-figures in demotic are notoriously difficult to read. A delay of 5 days is allowed in 1. 7, which gives a total of 92 days.

6. The supplement at the end of the line yields satisfactory sense, but is far too short to fill the lacuna.

7. The expression "necessarily and without delay" is extensively discussed by K. SETHE, Demotische Urkunden zum ägyptischen Bürgschaftsrechte vorzüglich der Ptolemäerzeit (AAWL 32), Leipzig, 1920, pp. 32-35. Other examples, for instance, in P. W. Pestman et al., Recueil de textes démotiques et bilingues III, Leiden, 1977, index, p. 55 ( $\left.\mathrm{n}^{\circ} 488\right)$ and p. $80\left(\mathrm{n}^{\circ} 606\right)$.

8 . For this problematical passage we partly follow a suggestion by M. Chauveau. In stead of "dispute with me" one expects "dispute with you". $m t w=y$ before "necessarily and without delay" normally can introduce the apodosis.

9. Here payment is apparently in kind, whereas in text $2,1.15$, it is in cash.

10. mtry is apparently followed by a flesh determinative and this makes the interpretation as "witness" doubtful. 


\section{Text 2}

Inventory number: pBud. E. 51.2172 B (pl. 2).

Four fragments of the same document, of which two can be joined directly. The margins are only preserved in the left upper corner.

Measurements: fragm. 1: 5.1 x $8.9 \mathrm{~cm}$; fragm. 3-4: 10 x $10.1 \mathrm{~cm}$; fragm. 5: 10.6 × $7.5 \mathrm{~cm}$.

Written against the fibres; the left upper corner is preserved and also part of the right margin. Date: about 150 or $135 \mathrm{BC}$, perhaps the same day as text 1, 17 March 148 (Ptolemy VI) or 14 March 137 BC (Ptolemy VIII).

\section{Transliteration}

Fragm. 1-3

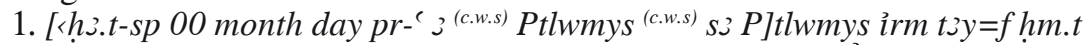

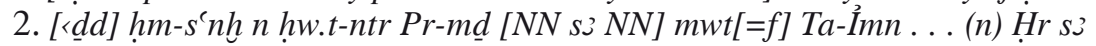
$W d \jmath-H r$

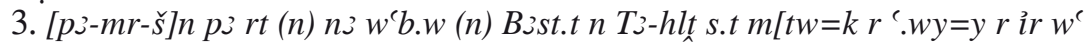
gu n] t3 hw.t-ntr

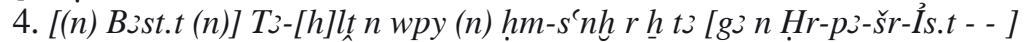

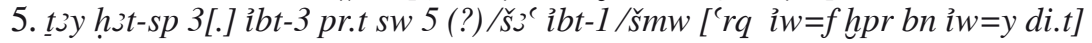

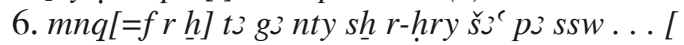

7. pз $m r-\check{s} n[. .$.$] hn hrw 5$ pз ỉbt m-š [

8. . . $d d=w$ irm $=y$ n rn nty $n b$ nty hry $m[t w$

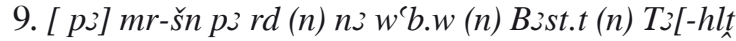

10. [ ] $m t w=y$ di.t. . . [

Fragm. 4 (with margin to the left)

11. $] n=y[$

12. ]...[

13. J T3-wr(.t) - - Tj-hlt

14. $]--n=y m t w . y r$

15. ] hd 3 r sttr 15

16. ] $r d($ ?) [

17. ] nty hry [

18. ] bn (?) [

19. ] . [ [

\section{Translation}

\section{Fragm. 1-3}

1. [Year 00, month day of pharaoh Ptolemy son of P]tolemy and his wife

2. has said the sculptor of the temple of Oxyrhynchus [NN son of NN, his] mother is Tamounis - - to Horos son of Oteyris

3. [the leson]is and representative of the priests of Bastet of Tholthis. [I have an obligation towards you to make a shrine (?)] in the temple]

4. [(of) Bastet in Tho]lthis as work of sculptor like the shrine of Harpochrates (?) - - ]

5. from year 3[.] Phamenoth 5 until Pachons [last day. If I do not] 
6. complete [it like] the shrine described above until the day [

7. the lesonis - - within 5 days of the month following [

8. - - they speak with me in the name of everything which is above [

9. - - the] lesonis the representative of the priests of Bastet of T[holthis

10. - - ] and I give [

Fragm. 4 (with margin to the left)

13. ] Thoeris (?) - - Tholthis

14. ] mentioned above [

15. ] 3 deben, i. e. 15 staters

16. ] representative(?) [

\section{Comments}

1. If our reading irm tzy $=f$ hm.t (a suggestion by K.-Th. Zauzich in 1989) at the end of line is exact, an unidentified queen, wife of the reigning king, is mentioned in the dating formula. We cannot, however, offer a parallel for this. In that case Ptolemy II is excluded, since Arsinoe II died in his $16^{\text {th }}$ year. In his $32^{\text {nd }}$ and $33^{\text {rd }}$ year Ptolemy VII was accompanied by two Kleopatras, his sister and his wife; therefore a date under Ptolemy VI for the whole group is perhaps preferable.

2. The line is only legible because we know from text 1 what is to be read. Reading the mother's name as Tamounis one could identify this person with the party of text 4 , but we cannot explain the signs following the doubtful Tamounis.

15. This formula, already attested in the $\mathrm{xxx}^{\text {th }}$ dynasty (E. LüDDECKENS, Ägyptische Eheverträge ( $\ddot{g} g$ Abh 1), Wiesbaden, 1960, 8 = pLondsdorfer I) indicates amounts of payments in money three times: 3 deben equals 15 staters [equals 10 deben again]. For money payments in demotic texts, see e.g. P. W. Pestman, L'archivio di Amenothes figlio di Horos, Milan, 1981, p. 29.

\section{Text 3}

Inventory number: pBud. E. 51.2172 C (pl. 3).

Measurements: 8.6 x $10.4 \mathrm{~cm}$.

The text is written along the fibres and has margins on three sides; it is broken off on the left only. The text is written with a broad brush and more difficult to read than the other fragments, also due to surface damage.

Date: 19 March 148 (Ptolemy VI) or 16 March 137 BC (Ptolemy VIII)

\section{Transliteration}

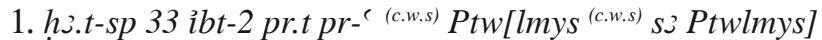

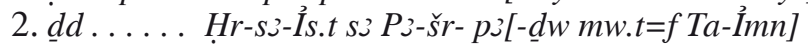

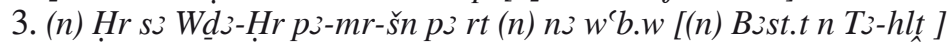

4. .... n wpy $(n)$ pз hm-s'nh tз gз [

5 . . . . hn pi $n k t(n) \dot{h} m-s^{\mathrm{e}} n h \mathrm{~h}[$

6. $i w=f$ hpr bn $i w=y$ di.t $m n q=f[$ 
7. $m n q$ tз $g 3 r n[=s$

$8 . \ldots t 3 \mathrm{~g}$ s $r n=s[$

9. . . . . su (?) Wd $3-H r \ldots$.

10. $n$ htr iwty mn. Sh ḩ3.t-sp 33 ibt-2 pr.t sw 22 [

11. $\underline{d} \dot{d} . . . \quad$ tz $\check{s}^{c}$.t nty hry $i w=y$ ir (?) $r \underline{h} .[t=f(?)$

\section{Translation}

1. Year 33 Mecheir of king Pto[lemy son of Ptolemy]

2. has said the occupation Harsiesis son of Psenp[djou his mother being Tamounis to]

3. Horos son of Oteyris the lesonis and representative of the priests of [Bastet of Tholthis. I have an obligation towards you to make a shrine (?) in (?) the temple]

4. [of Bastet in Tholthis as] work of sculpture of the shrine - -

5. [ ] ] in the matter of sculptor (?) [

6. If I have not completed it [

7. complete the named shrine [

8. - - the named shrine

9. - - - - son of (?) Oteyris (?)

10. necessarily without delay. Written in year 33 Mecheir day 22.

11. said - - - the above document, I will act accordingly [

\section{Comments:}

2. Before the name Harsiesis an occupation like "sculptor" is expected, but the word is not $h m-s^{\prime} n h$ as in texts 1 and 2. The first letter could be a $b$, but bsnty "blacksmith", tentatively suggested by M.-P. Chauffray, does not seem likely. It seems to start with an aleph and may include the sign of wood. We have identified Harsiesis with his homonym in text 4 and hence supplied the name of his parents here. Identification with the first party of text 2 is not excluded, but the title is different and the reading of the mother's name Tamounis there is doubtful.

3-4. On the basis of texts 1 and 2 we expect here [s.t $m t w=k r^{c}$. wy $w y$ ir

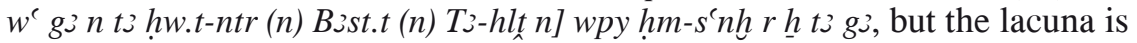
not long enough for all this and before $t_{3} g 3$ the word $r \underline{h}$ "like" is absent here. Apparently the clause is somewhat different here. 1. 5 .

5. $h n$ pj $n k t(n) h m-s^{\prime} n h$ : the same expression is probably found in text 4 ,

6. Cf. text 1, 11. 5-6 and 2, 11. 5-6 for this formula.

9. It is hardly possible to read here the name and patronymic of the lesonis $H r$ si $W \underline{d} \dot{\jmath}-H r$. 


\section{Text 4}

Inventory number: P. Bud. E. 51.2172 D (pl. 4).

Measurements: fragm. $1: 6.8$ x $8 \mathrm{~cm}$; fragm. $2: 5.9$ x $7.2 \mathrm{~cm}$.

Date: about 148 BC or 137 BC?

This text is broken in two fragments, which do not join.

\section{Transliteration}

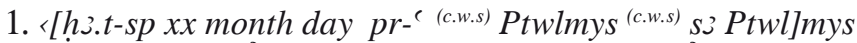

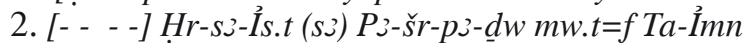

3. [ - - - NN pз-mr-šn pj rt (n) nз w']b.w (n) Bзst.t n Tz-hlt s.t

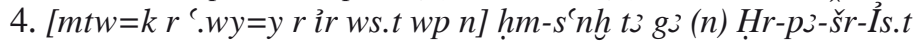

5. [- - - ]. . hn $\mathrm{h}$ j $n k t$

6. [- - ] hm-s'nh iw $\mathrm{l}=\mathrm{fhpr} r$ bn

7. $[---]$.

$-\cdot-$

8.... [

9. $r$-di.y.... [

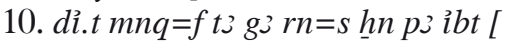

11. $\left\langle h m-s^{e} n h\right.$ h $i w=y$ di.t $p$ j [

12. rn t3 wp.t h[m-s'nh

13. nty $n b$ [

\section{Translation}

1. [Year xx month day king Ptolemy son of Ptole]my

2. [- - - Harsiesis son of Psenpdjou and Tamounis

3. - - - [ to NN the lesonis and the representative of the priests of] Bastet of Tholthis:

4. [I have an obligation towards you - - ] the shrine of Harpochrates

5. ??

6. - - - sculptor. If I donot - -

10. to make complete the named shrine in the month [

11. sculptor I will give the [

12. in name of the work of s[culptor (?)

13. all [

\section{Comments}

1. The expression [sऽ Ptwl]mys on the left hand fragment, read independently by U. Luft and by M. Depauw, and strongly suggests this fragment contains the end of the royal titulature in 1.1 .

2. Harsiesis is the same person as in text 3, and perhaps he is also the first party of text 2 (see note there). The patronymic is clearly legible, but apparently unique. As suggested by M. Chauveau, the divine component is apparently the young bird, followed by a god's determinative and a bird determinative; for the reading $\underline{\mathrm{dw}}$, see for instance Demotisches Namenbuch, p. $1355-1356$. 


\section{Text 5}

Inventory number: pBud. E. $51.2172 \mathrm{E}$ (pl. 5).

Measurements: $7.2 \times 5.9 \mathrm{~cm}$ (margin preserved at top and to the right).

\section{Transliteration}

1. «h3.t-sp 32 ibt-3 pr.t sw 2[.] [

2. iw =f hpr pз . . tз hw.t-ntr Bзst.t [

3. [...]... sinh [

\section{Transliteration}

1. Year 32, Phamenoth 2[. of king Ptolemy son of Ptolemy - - ]

2. [if the ... of the temple] of Bastet [

3. [- - ] sculptor (?) [

\section{Comments}

2. The second line begins with a conditional sentence and this is different from the preceding texts. The end of the line has the name of Bastet, preceded by a place determinative and god's determinative; the reading seems therefore assured. The single masculine word between $i w=f h p r$ and the nearly illegible $h w . t-n t r$ is largely lost. One does of course expect the title $h m-s^{\prime} n h$, but the traces do not seem to fit this; moreover one should also have the name and identification of the first party and there is no place for that. Apparently the contract starts with a condition like "if the work is given to NN, then he says", cf. the offers for hiring shrines or doing a job for the temple in pOxf. Griffith 42-55, where, however, the name of the bidder precedes the conditional sentence. 
Planche 1 : Text 1. P. Bud. E 51.2172 A.
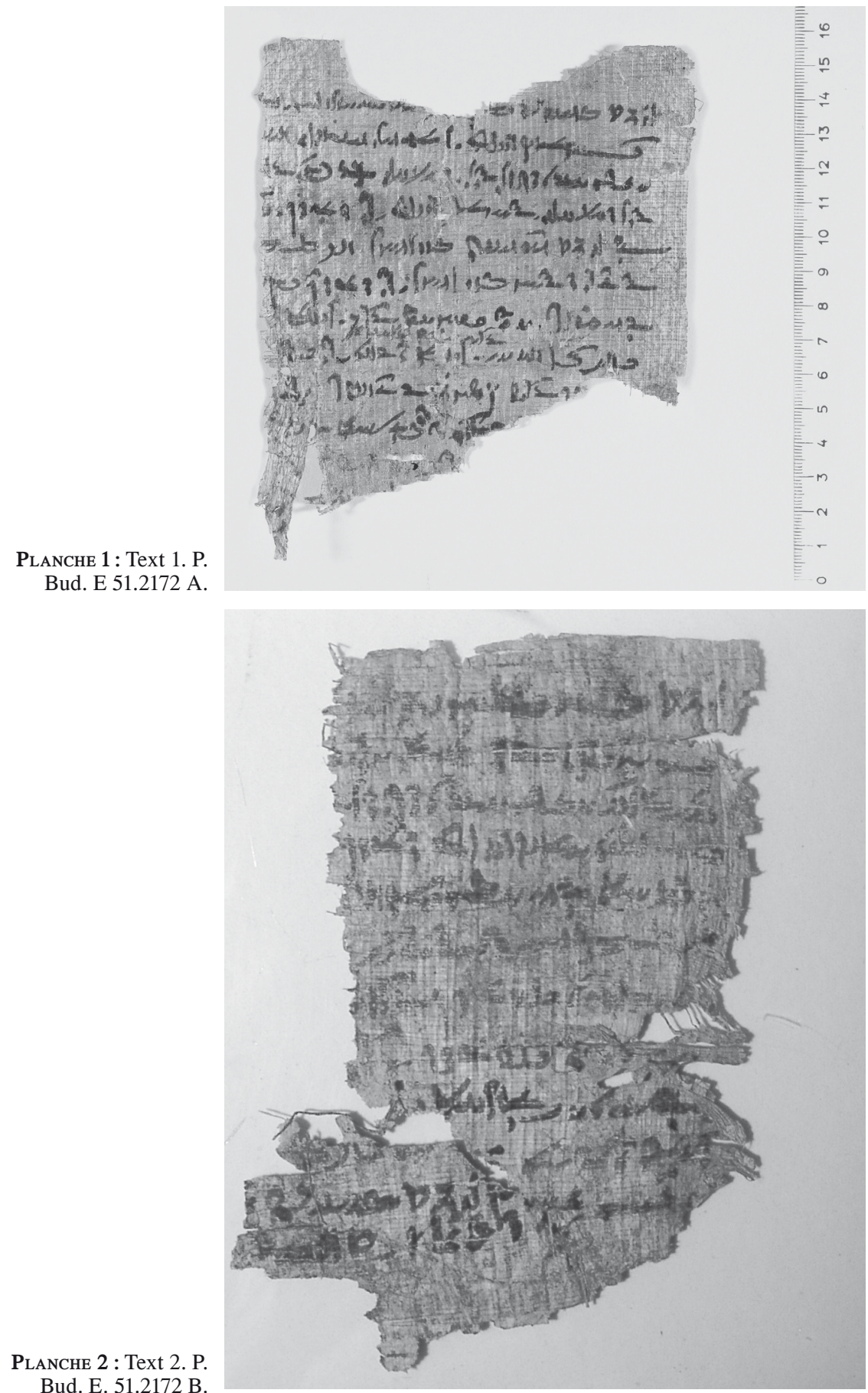


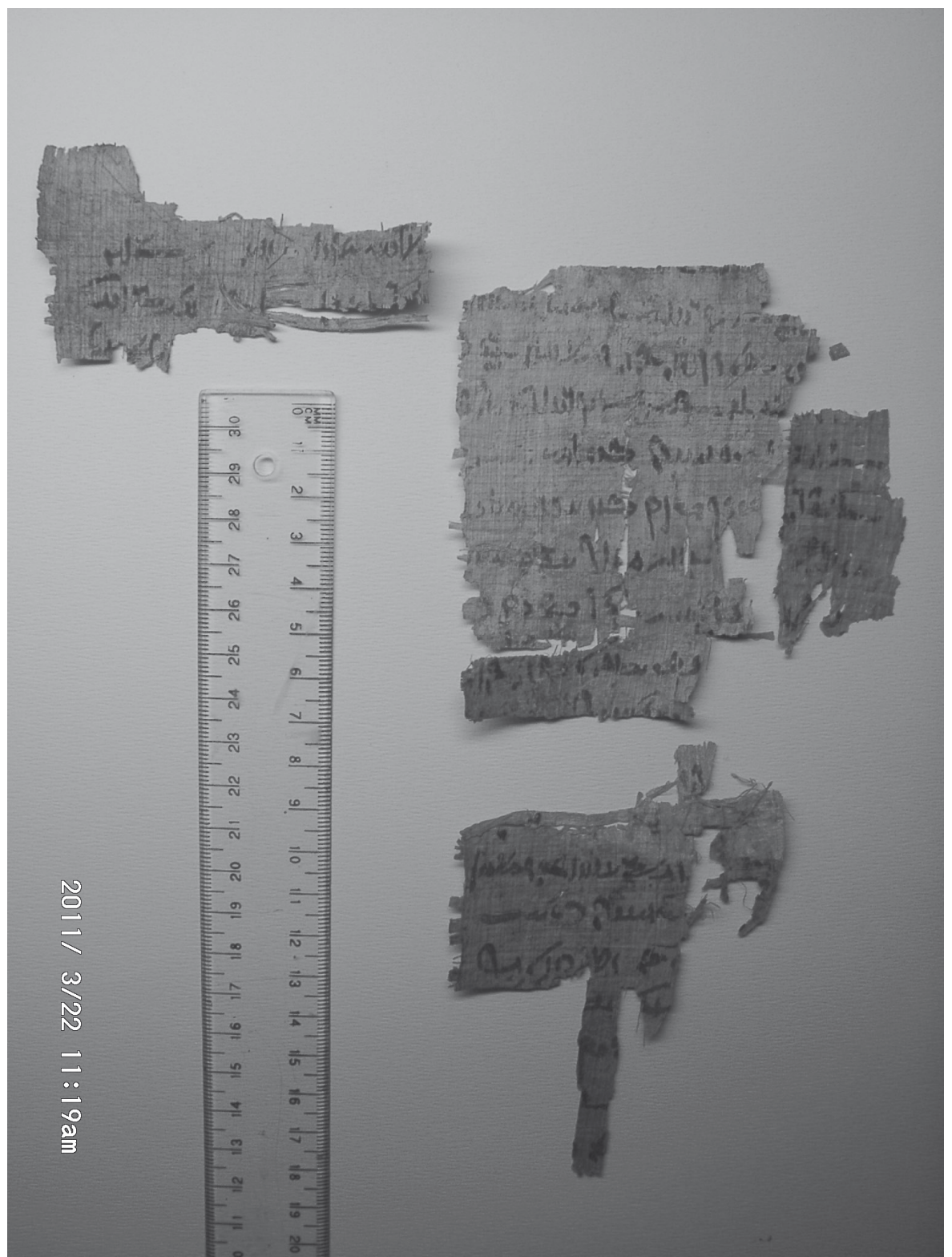

Planche 3 : Text 3. P. Bud. E. 51.2172 C. 
Willy Clarysse, Ulrich Luft

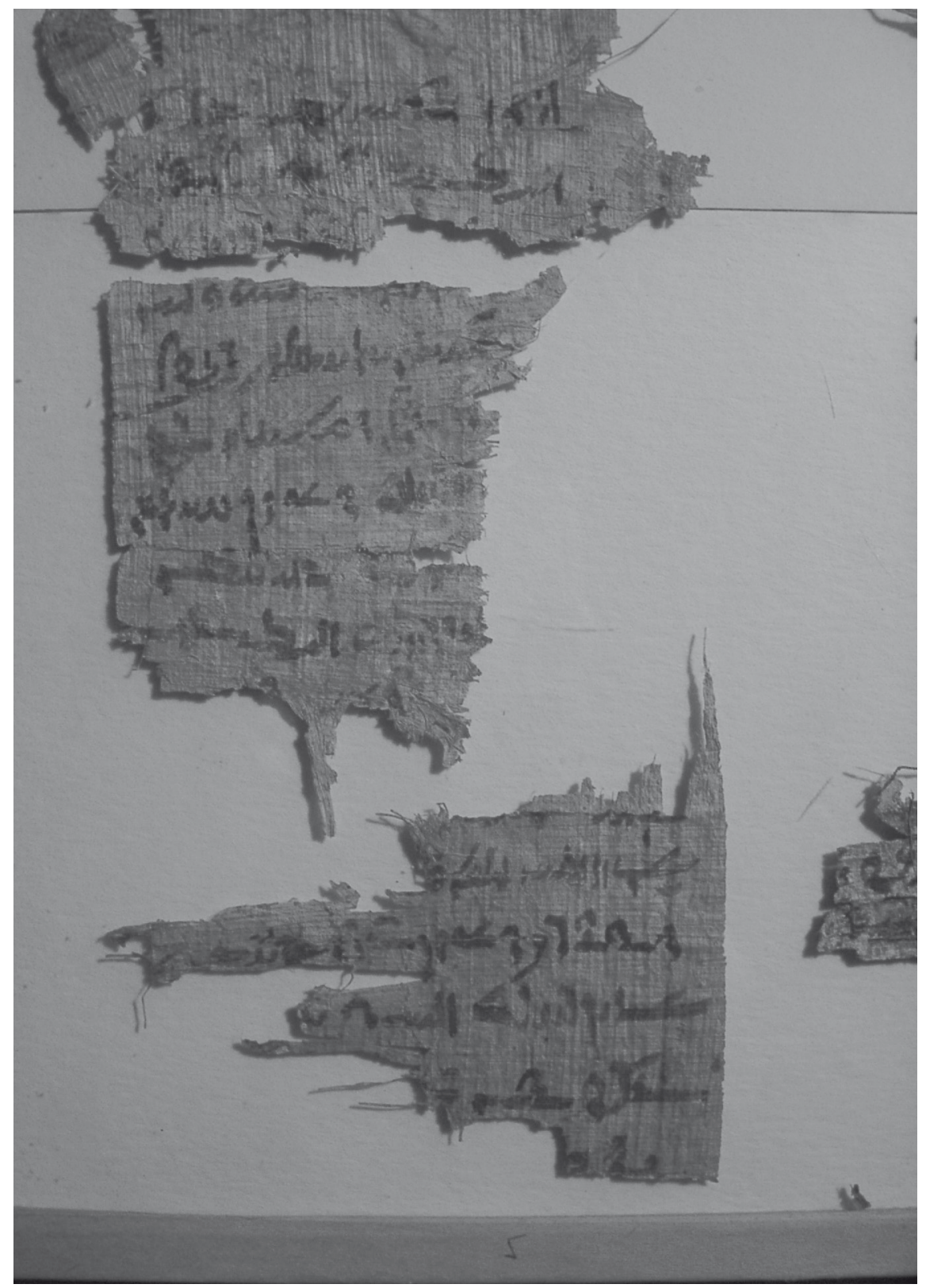

Planche 4 : Text 4. P. Bud. E. 51.2172 D. 


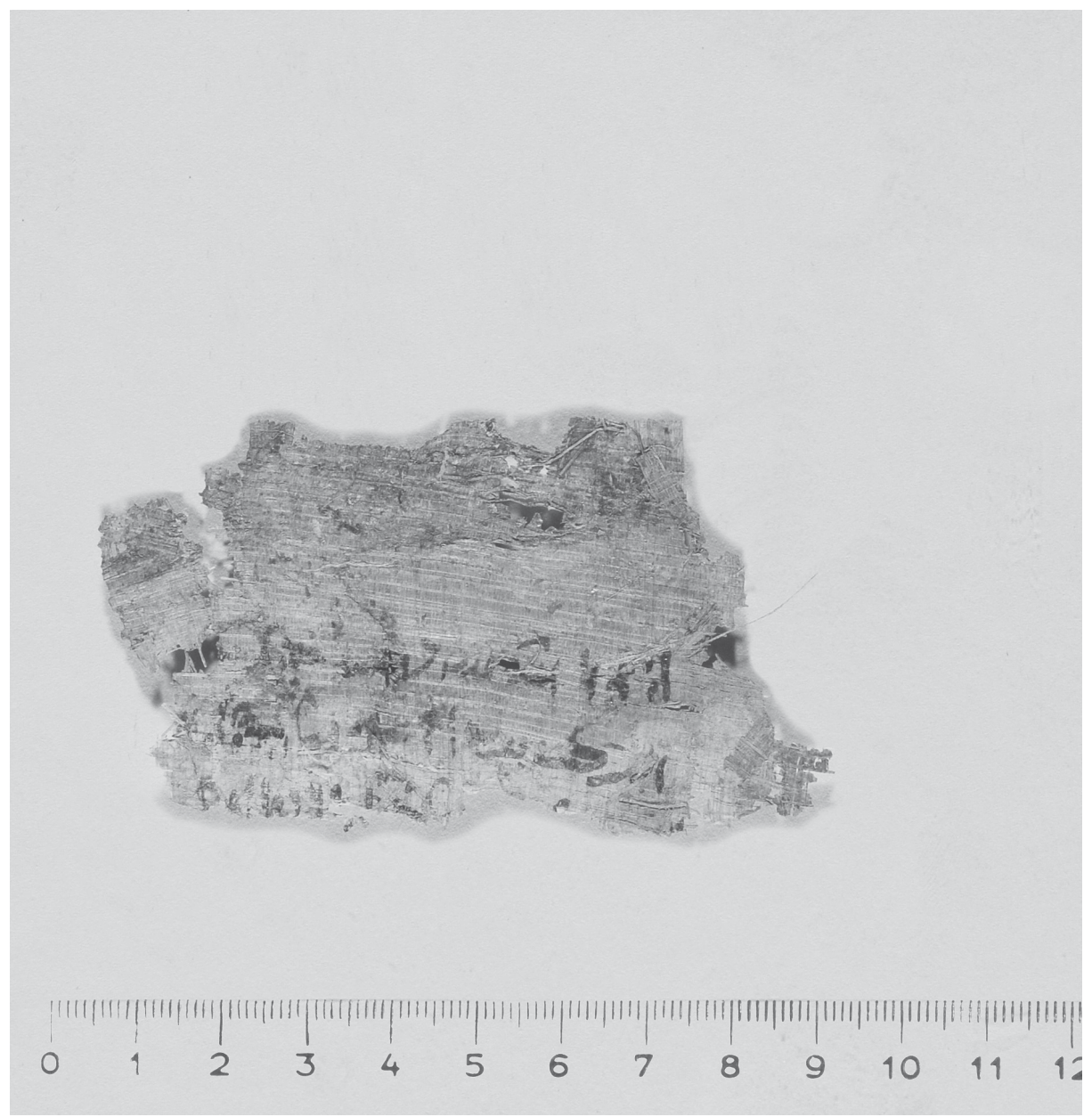

Planche 5 : Text 5. P. Bud. E. 51.2172 E. 
